

\section{The Australian \\ Educational and Developmental Psychologist}

\section{Editor}

Chris Boyle

Associate Editors

Tim Corcoran

Victoria University, Australia

John Roodenburg

Monash University, Australia

\section{Book Reviews Editor}

Gerald Wurf

Charles Sturt University, Australia

Editorial Board
Jean Annan
Massey University, New Zealand
Fiona Bryer
Griffith University, Australia
Cheryl Dissanayake
LaTrobe University, Australia
Janet Fletcher
University of Western Australia, Australia
Erica Frydenberg
University of Melbourne, Australia
Frances Gibson
Macquarie University, Australia
Linda Gilmore
Queensland University of Technology,
Australia

John Hattie

The University of Melbourne, Australia

Kit-Tai Hau

The Chinese University of Hong Kong, Hong Kong

Garry Hornby

University of Canterbury, New Zealand

Stephen Houghton

The University of Western Australia

Andrew Martin

The University of Sydney, Australia

Nancy Mather,

University of Arizona, USA

Dennis Mclnerney

The Hong Kong Institute of Education, Hong Kong

Magdalena Mo Ching Mok

The Hong Kong Institute of Education,

Hong Kong: Editor of Educational Psychology

Ian Shochet

Queensland University of Technology, Australia

Statistical Consultants:

Shane Costello

Monash University, Australia

Kate Jacobs

Monash University, Australia

Journal Admin

Jake Kraska

Monash University, Australia
The Australian Educational and Developmental Psychologist (AEDP) is now in its 30th year and has a proud tradition of disseminating both practice and academic based research and discussion papers in wide ranging areas of educational and developmental psychology. The principal purpose of this journal will continue to be to provide the members of the Australian Psychological Society's College of Educational and Developmental Psychologists with quality discussion and scientifically sound research which furthers psychology.

The journal employs a rigorous editorial review process whereby manuscripts are reviewed by the Editor and at least two members of the Editorial Board or the list of reviewers. Submitted manuscripts are welcomed in wide areas of educational and developmental psychology which can include empirical studies (qualitative or quantitative), reviews of current research, and position papers. The Editor welcomes communication regarding proposals for submissions. From time-to-time there will be special issues on a particular theme and enquiries are invited for guest editorships of special editions.

Manuscripts from practising psychologists which are relevant to the field are especially welcomed by the Editor. School psychology as an international discipline is an area which the Editor is keen to promote through the AEDP and international submissions are especially welcomed in order to complement Australian psychological practice. This journal is published by the Australian Psychological Society (via Cambridge University Press) but editorial independence is maintained by the Editor. To this end, the scholarly strengths of the manuscript are the only considerations when deciding on the merits of a submission to the journal. Currently the AEDP is published twice a year online and in print but plans are afoot to increase the number of issues per year.

\begin{tabular}{|c|c|c|}
\hline \multicolumn{3}{|c|}{ APS College of Educational and Developmental Psychologists National Committee 2013} \\
\hline $\begin{array}{l}\text { Chair } \\
\text { Paul Bertoia } \\
\text { Email: paul.bertoia@education.tas.gov.au } \\
\text { Deputy Chair } \\
\text { Vacant } \\
\text { Chair of the Course Approvals Committee } \\
\text { John Roodenburg } \\
\text { Email: john.roodenburg@monash.edu.au } \\
\text { Treasurer } \\
\text { Kelly Allen } \\
\text { Email: kellya@toorakc.vic.edu.au } \\
\text { Secretary (Acting) } \\
\text { Gerald Wurf } \\
\text { Email: gwurf@csu.edu.au } \\
\text { Membership Secretary } \\
\text { Linda Gilmore } \\
\text { Email: I.gilmore@qut.edu.au } \\
\text { Chair of the Continuing PD Committee / } \\
\text { NewsletterEditor } \\
\text { Vicki McKenzie } \\
\text { Email: v.mckenzie@unimelb.edu.au }\end{array}$ & $\begin{array}{l}\text { Journal Editor } \\
\text { Chris Boyle } \\
\text { Email: christopher.boyle@monash.edu } \\
\text { Webmaster } \\
\text { Kelly O'Brien } \\
\text { Email: kellyo@toorakc.vic.edu.au } \\
\text { Darren Stops } \\
\text { Email: darren_stops@yahoo.com } \\
\text { Kelly Allen } \\
\text { Email: kellyo@toorakc.vic.edu.au } \\
\text { Student Representative } \\
\text { Judy Crigan } \\
\text { Email: j.crigan@unimelb.edu.au } \\
\text { APS Psychologists in schools advisor } \\
\text { Darren Stops } \\
\text { State Representatives } \\
\text { Lizette Campbell (NSW) } \\
\text { Email: j.crigan@unimelb.edu.au } \\
\text { Tim Connell (South Australia) } \\
\text { Email: tim.connellpsych@bigpond.com }\end{array}$ & $\begin{array}{l}\text { Santo Russo (Queensland) } \\
\text { Email: santo@betterlife.com.au } \\
\text { Tara Hawkins (Western Australia) } \\
\text { Email: tarahawkins@live.com.au } \\
\text { Lesley Fraser (Tasmania) } \\
\text { Email: lesley.fraser@education.tas.gov.au } \\
\text { Committee Members } \\
\text { Jo Milne-Holme } \\
\text { Email: J.Milnehome@uws.edu.au } \\
\text { Terry Bowles } \\
\text { Email: tbowles@unimelb.edu.au } \\
\text { Early Intervention Representative / } \\
\text { Committee Member } \\
\text { Janene Swalwell } \\
\text { Email: janeneswalwell@gmail.com } \\
\text { Committee Member / Older Persons } \\
\text { Representative } \\
\text { Lydia Hohaus } \\
\text { Email: I.hohaus@griffith.edu.au }\end{array}$ \\
\hline
\end{tabular}

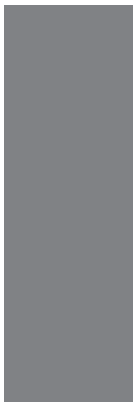

Subscription Rates 2013

This journal is published twice a year.

The institutional rates (excluding VAT) are:

Australia

N America

UK and ROW

Print and online
198 AUD
233 USD
150 GBP

Electronic only

189 AUD

216 USD

$140 \mathrm{GBP}$

EU subscribers (outside the UK) who are not registered for VAT should add VAT at their country's rate. VAT registered subscribers should provide their VAT registration number. Prices include delivery by air when appropriate. Japanese prices for institutions are available from Kinokuniya Company Ltd, P.O. Box 55, Chitose, Tokyo 156, Japan.

\section{Orders and subscription enquiries should be addressed to:}

Cambridge University Press, The Edinburgh Building, Shaftesbury Road, Cambridge CB2 8RY, UK

\section{Orders from N America should be addressed to:}

Cambridge University Press, Journals Fulfillment Department, 100 Brook Hill Drive, West Nyack, NY 10994-2133, USA

The Australian Educational and Developmental Psychologist and all other Cambridge Journals can be found at http://journals.cambridge.org/ 


\section{The Australian \\ Educational and \\ Developmental \\ Psychologist}

Volume 30 No. I

2013
Published by Cambridge University Press on behalf of Australian Academic Press Pty Ltd. and The Australian Psychological Society.

Cambridge University Press,

University Printing House

Shaftesbury Road

Cambridge CB2 8BS

United Kingdom

journals.cambridge.org

\section{Editorial}

The Future is Bright: The Future is Educational and Developmental Psychology

\section{Commentary}

A Commentary on the Current and Future Status of Educational and Developmental Psychology in Australia

Linda Gilmore, Janet Fletcher and Alan Hudson

\section{Articles}

Problematising Style Differences Theory and Professional Learning in Educational Psychology

Stephen G. Rayner

Understanding the Profession of Educational Psychology in England: Now and in the Future

Brahm Norwich

Perceptions and Realities: The Role of School Psychologists in Melbourne, Australia

Henry D. Bell and Vicki McKenzie

Educational Psychologists as Researchers

Keith Topping and Fraser Lauchlan

An Initial Investigation of an Australian

Adaptation of the Multidimensional Aptitude Battery - II

Kate E. Jacobs and Shane Costello

\section{Book Review}

Mindfulness for Life 